\title{
Inventarisasi Teritip Non-Indigenous yang Menempel pada Ocean Going Vessel di Pelabuhan Tanjung Intan Cilacap
}

\author{
Romanus E Prabowo dan Erwin R Ardli
}

Fakultas Biologi Universitas Jenderal Soedirman, Jalan Dr. Suparno 63 Purwokerto, 53122

\begin{abstract}
Port of Tanjung Intan Cilacap is one of four major international shipping ports located in Jawa Island and among 85 ports throughout Indonesia. International shipping ports are exposed for non-indigenous species including barnalces as a consequence of shipping traffic. Barnacle is the most common marine fouling found in ship's hull and ballast water of ocean going vessel. This work was aimed at knowing which barnacle species were passively transported on such vessels hulls, in order to map and monitor non-indigenous species invasion in the area. Four vessels of different origins were investigated between April and November 2009. Among four vessels, three of them were clean. A cosmopolite non-invasive species were found on a ship of Ukrainan origin, Amphibalanus amphitrite., which also occur dominantly in the port of Tanjung Intan Cilacap. This port was considered at no introduction risk of non-indigenous species.
\end{abstract}

Key words: invasive, non-indigenous, introduksi, konservasi, biofouling.

\section{Pendahuluan}

Indonesia memiliki 85 pelabuhan laut yang terbuka untuk pelayaran internasional. Pelabuhan-pelabuhan tersebut sangat terbuka terhadap kehadiran global invasive species yang hidup sebagai biofouler pada kapal-kapal internasional, dimana teritip adalah salah satu komponen utama biofouler pada kapal laut. Keberhasilan introduksi spesies non-indigenous bisa mengancam keanekaragaman hayati dan ekosistem lokal, yang bila terganggu atau rusak, baik secara langsung maupun tidak, bisa juga merusak sumber-sumber ekonomi bahari dan upaya-upaya konservasi lingkungan lokal.

Kapal laut adalah vektor terbesar dalam penyebaran spesies invasive global. Godwin (2003) menjelaskan bahwa kapal dapat menjadi 'pulau' sebagai batu loncatan yang efektif untuk spesies yang hidup di pelabuhan dan estuaria, karena kapal merupakan substrat yang pas untuk menempel bagi spesies-spesies komunitas biofouling. Oleh karena itu perhatian dan kewaspadaan terhadap kapal-kapal internasional perlu ditingkatkan karena resiko yang ditimbulkannya bisa sangat menelan biaya dan menimbulkan kerugian yang tidak sedikit (Wolff, 2005).

Penelitian serupa sudah pernah dilakukan sebelumnya oleh Otani et.al. (2007) terhadap 2 kapal bulk carrier yang melayari rute Australia - Indonesia - Jepang yang singgah di pelabuhan Teluk Osaka. Ditemukan 22 spesies teritip dewasa pada kedua kapal tersebut, dimana 14 diantaranya adalah spesies invasive dan 2 diantaranya dikategorikan memiliki resiko (peluang) tertinggi untuk introduksi, yaitu Austrominius modestus dan Amphibalanus variegatus. Namun demikian meskipun kondisi lingkungan perairan Jepang dan Australia relatif sama, sangat mendukung dan memungkinkan untuk terjadinya proses introduksi, singkatnya batas waktu lama singgah kapal telah mengurangi peluang introduksi teritip-teritip tersebut ke lingkungan Teluk Osaka.

Penelitian terkini mengenai biofouler teritip dilakukan oleh Yamaguchi et.al. (2009) terhadap jenis teritip Megabalanus coccopoma dari tiga populasi yang berbeda (Brazil, 
Australia dan Jepang) dimana habitat asli dari spesies ini adalah Panama. Hasil menunjukan bahwa perbedaan kondisi lingkungan dan jauhnya jarak tidak membatasi invasi dan introduksi spesies tersebut. Studi genetika populasi menunjukan bahwa ketiga populasi tersebut adalah satu populasi yang berasal dari populasi asalnya yaitu Panama. Ketiga populasi tersebut adalah sebagai hasil introduksi dan bukan merupakan distribusi alamiahnya, yang pada perkembangannya terakhir ini telah mendominasi beberapa perairan pantai Jepang dan Australia. Di Jepang spesies ini banyak merusak tiang pancang dan tali untuk budidaya tiram dan menjadi hama budidaya tiram yang cukup merepotkan, sementara di Australia menjadi kompetitor yang dominan bagi spesies lokal.

Banyak contoh negatif dari kasus spesies invasive global. Kasus yang terdokumentasi pertama kali adalah spesies teritip Austrominius modestus (=Elminius modestus), dari New Zealand ke Inggris, yang besar kemungkinannya dibawa pada saat konvoi kapal perang dan logistik selama Perang Dunia II (Southward et al, 1998), yang sekarang menjadi sangat dominan di pantai-pantai Inggris, spesies tersebut telah menjadi pesaing yang sangat kuat bagi spesies lokal untuk mendapatkan ruang hidup. Contoh destruktif adalah kehadiran 'The Death Weed' Caulerpa taxifolia. Spesies ini adalah alga hijau (makroalga Chlorophyta) dengan distribusi alami sepanjang daerah tropis dan subtropis termasuk bagian utara Australia. Tumbuhan subtidal yang tumbuh menjalar baik pada substrat keras maupun lunak, dilaporkan ada di perairan dekat Monaco Oceanographic Aquarium di Mediterrania untuk pertama kali pada tahun 1984, yang hanya menutupi area seluas 1 meter persegi. Rekor tersebut juga merupakan rekor pertama spesies tersebut ditemukan di perairan hangat. Namun perkembanggan berikutnya telah menutupi daerah hingga 3 hektar (ha) pada tahun 1990, 30 ha pada tahun 1991, 427 ha pada tahun 1992, 1.300 ha pada tahun 1993, dan lebih dari 3.000 ha pada tahun 1996. Penutupan alga yang sedemikian luas telah merubah (merusak) eskosistim lokal dan merubah rantai makanan spesies-spesies lokal (lanProvost, 2004).

Banyak contoh destruktif lain; seperti kehadiran bintang laut Jepang Asterias amurensis yang sekarang mendominasi pantai dangkal Melbourne Australia yang terbawa bersama air balas kapal dan anjungan lepas pantai yang dibawa dari Jepang, yang telah merusak ekosistem pantai dangkal Melbourne karena populasinya yang tidak bisa dikontrol karena tidak adanya musuh alaminya di perairan Australia, dimana kerapatan populasinya bisa mencapai 50 ekor per meter persegi (Lewis pers.com., 2008). Dari uraian tersebut di atas mengenai beberapa contoh negatif invasi spesies asing pada suatu ekosistem, sudah cukup menggambarkan mengenai resiko dan ancaman serius dari hadirnya spesies invasive.

Bidang kajian invasi spesies laut ini termasuk baru di dunia international (lan LeProvost, 2004), yang sudah dimulai oleh beberapa negara maju dan beberapa negara yang memiliki pelabuhan laut seperti Uni Eropa, Amerika Serikat, Australia - New Zealand dan Jepang. Indonesia saat ini bukan termasuk negara yang terlibat secara aktif dalam pelaporan temuan global invasive species pada berbagai organisasi yang menangani invasi spesies laut regional maupun international. Banyaknya organisasi internasional yang menangani spesies invasive menunjukan perhatian negara-negara yang terlibat di dalamnya mengenai resiko dan ancaman yang serius dari masalah spesies invasive. Pimentel et.al. (2000) melaporkan bahwa kerugian dan biaya yang ditanggung oleh Amerika Serikat akibat spesies invasive adalah sebesar US\$138 juta per tahun, suatu angka dan gambaran yang sangat mahal untuk penanganan hama 
spesies invasive pertanian dan maritim. Indonesia saat ini belum terlibat secara aktif dalam jejaring internasional untuk melaporkan temuan global invasive species pada berbagai organisasi yang menangani invasi spesies laut global baik regional maupun internasional.

Permasalahan yang melatarbelakangi penelitian ini adalah tingginya resiko dan besarnya ancaman dari spesies invasive global terhadap ekosistem pesisir laut Indonesia, dan gagasan utama usul penelitian ini adalah konservasi lingkungan, deteksi dini dan proteksi keanekaragaman hayati pesisir laut Indonesia dari ancaman spesies invasive yang mungkin datang bersama kapal laut internasional. Oleh karena itu penelitian ini ditujukan untuk mencari data keberadaan dan keragaman spesies teritip yang menempel pada kapal (ship-biofouler) di pelabuhan Tanjung Intan Cilacap, mencari data keberadaan dan keragaman spesies teritip yang menempel pada lingkungan pelabuhan Tanjung Intan Cilacap, serta mencari ada tidaknya spesies teritip invasive.

\section{Materi dan Metode}

Penelitian ini dilaksanakan di pelabuhan internasional Tanjung Intan Cilacap. Pelabuhan tersebut dipilih karena merupakan pelabuhan ekspor dan impor barang dan minyak bumi yang waktu sandarnya relatif lama dan frekwensi kedatangannya yang cukup tinggi. Lokasi penelitian adalah pada badan (lambung) kapal sampel dan lingkungan pelabuhan itu sendiri. Penelitian tahun pertama dilaksanakan dalam 8 bulan, dari bulan April - November 2009.
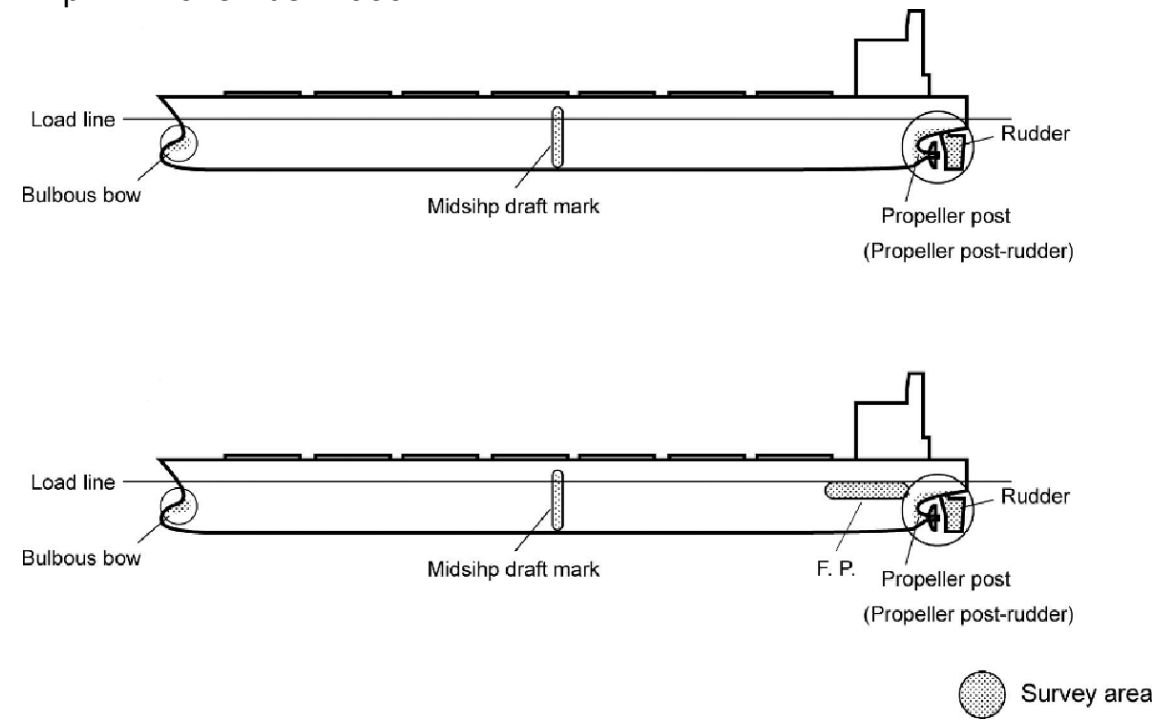

Gambar 1. Titik-titik pengambilan sampel teritip dari lambung kapal; bulbous-bow (ujung depan), mid-ship draft mark (bagian tengah), dan propeller post-rudder (ujung belakang).

Figure 1. Sampling sites on ship's hull; bulbous-bow, mid-ship draft mark, and peopeller post rudder

Penelitian ini adalah survei yang merupakan penelitian deskriptif, guna membuat gambaran biodiversitas dan adanya kehadiran spesies teritip asing, secara sistematis, faktual dan akurat. Data kapal (asal dan tujuan serta lama sandar kapal) diperoleh dari 
otoritas kedua pelabuhan tersebut di atas (Administrator Pelabuhan - ADPEL). Kapal rute international dengan waktu sandar di pelabuhan yang paling lama dipilih, dengan pertimbangan tersedia waktu yang cukup untuk proses pindah (transfer) dan penambatan kembali (resettlement) oleh spesies invasive dewasa ataupun larvanya dari kapal ke lingkungan pelabuhan (daratan).

Pengambilan sampel teritip secara kualitatif pada bagian terendam lambung kapal dilakukan dengan penyelaman (SCUBA-diving) pada bagian bulbous-bow (ujung depan), mid-ship draft mark (bagian tengah), dan propeller post-rudder (ujung belakang) (Gambar 1). Sampel kemudian disimpan dalam ethanol 99\% untuk selanjutnya dilakukan identifikasi spesies di laboratorium. Ethanol dengan konsentrasi 99\% diperlukan untuk penyimpanan koleksi spesimen untuk kurun waktu yang lama dan bila kemudian diperlukan bisa digunakan untuk analisa lanjutan (misalnya identifikasi spesies berdasarkan sekuens DNA-nya atau DNA-barcodding). Sampel larva invertebrata laut juga diambil dari kapal yang membuang ballast-water pada saat sandar di pelabuhan dengan menggunakan plankton-net. Sampel kemudian diberi fiksatif dan penanda rose-bengal, dan kemudian akan diidentifikasi jenisnys di laboratorium.

Identifikasi spesies teritip dilakukan di Laboratorium Biologi Akuatik Fakultas Biologi Universitas Jenderal Soedirman. Penentuan spesies non-indigenous didasarkan pada catatan ilmiah penelitian taksonomi dan biodiversitas invertebrata laut daerah penelitian melalui penelusuran pustaka, dan juga mengacu pada Global Invasive Species Database milik Global Invasive Species Programe (GISP) yang bisa diakses secara online.

\section{Hasil dan Pembahasan}

Pelabuhan Tanjung Intan Cilacap mempunyai kedalaman pelabuhan sekitar 15 meter pada saat surut hingga bisa langsung disinggahi oleh kapal internasional. Namun demikian frekwensi kapal yang masuk ke Pelabuhan Tanjung Intan Cilacap sangat rendah, sehingga selama kurun waktu pengambilan sampel hanya empat kapal internasional saja yang memenuhi syarat disampling. Syarat dari kapal internasional yang bisa disampling adalah kapal tersebut melayari pelabuhan yang berada pada zona zoogeofrafis teritip yang berbeda. Sehingga meskipun ada kapal asing dari negara tetangga di Asia Tenggara, kapal tersebut tidak memenuhi syarat untuk disampling. Identitas seluruh nama kapal tidak bisa dilaporkan disini sesuai dengan kesepakatan dengan pengelola kapal, dan digantikan dengan identitas pengganti yaitu Kapal ' $A$ ', ' $B$ ', 'C', dan ' $D$ '.

Data teritip dewasa yang diperoleh dari badan kapal menunjukkan sangat rendahnya biodivesitas tertitip yang diperoleh dari lambung kapal terpilih. Dari empat kapal yang disampling 3 diantaranya baru dibersihkan dan dicat. Hanya ditemukan 1 jenis teritip non-invasive dari empat kapal yang disampling di Pelabuhan Tanjung Intan Cilacap yaitu Amphibalanus amphitrite (Gambar 2.A.; Gambar 3) yang merupakan spesies kosmopolit yang juga ada di lingkungan pelabuhan Tanjung Intan Cilacap. Rute pelayaran kapal yang dupilih sebenarnya sudah dapat mewakili zona fauna teritip yang berbeda, yaitu dari daerah tropis Madagaskar, daerah tropis Amerika, dan daerah tropis Australia, sedangkan satu sisanya berasala dari daerah dingin Ukraina. 
Data pengambilan sampel teritip dewasa di kedua lokasi penelitian disajikan pada Table 1.

Tabel 1. Data pengambilan sampel teritip dewasa di lambung kapal dan di pelabuhan.

Table 1. Sample collection data of adult barnacle on ships hull and in port

\begin{tabular}{|c|c|c|c|c|}
\hline \multirow[t]{2}{*}{ No. } & \multirow[t]{2}{*}{ Kapal } & \multirow[t]{2}{*}{ Rute } & \multicolumn{2}{|c|}{ Spesies teritip temuan } \\
\hline & & & di pelabuhan & $\begin{array}{c}\text { di lambung } \\
\text { kapal }\end{array}$ \\
\hline 1. & Kapal 'A' & Amerika Tengah - Cilacap & Amphibalanus amphitrite & - \\
\hline 2. & Kapal 'B' & Darwin Australia - Cilacap & A. reticulatus & - \\
\hline 3. & Kapal C' & Madagaskar - Cilacap & A. variegatus & - \\
\hline 4. & Kapal D' & Ukraina - Cilacap & Cthamalus malayensis & A. amphitrite \\
\hline
\end{tabular}

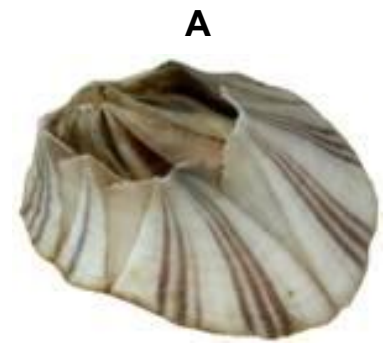

C

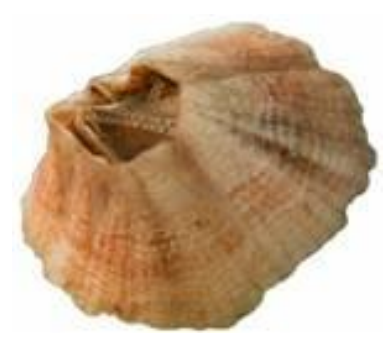

B

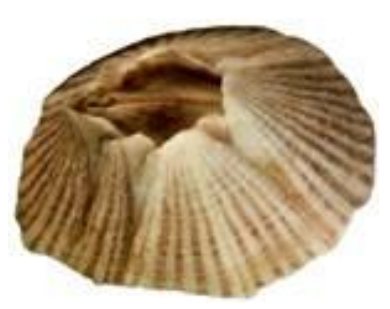

D

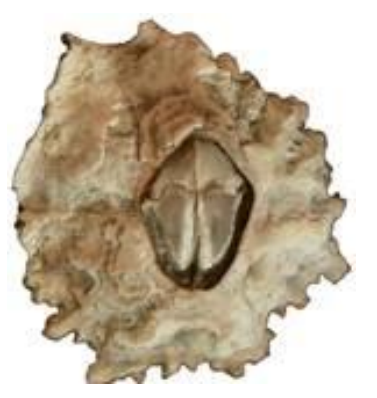

Gambar 2. Empat spesies yang terdapat di pelabuhan Tanjung Intan Cilacap. A. Amphibalanus amphitrite, B. A. reticulatus, C. A. variegatus, dan C. Chthamalus malayensis.

Figure 2. Four species found at Tanjung Intan Port Cilacap. A. Amphibalanus amphitrite, B. A. reticulatus, C. A. variegatus, dan C. Chthamalus malayensis.

Pada penelitian kali ini sebagaimana penelitian-penelitian serupa yang sudah dilaksanakan sebelumnya, teritip umum ditemukan pada bagian lambung belakang kapal, yaitu de depan dan di belakang propeler kapal, daerah ini disukai karena beberapa spesies teritip menyukai air yang berarus kencang.

Penelitian ini juga tidak menemukan adanya spesies invasive global. Hal ini dikarenakan manajemen pencegahan yang sudah bagus, dimana air balas 
(ballast-water) dibuang di lepas pantai sebelum memasuki pelabuhan, dan kapal dibersihkan dan dicat antifouling secara rutin.

Sementara itu biodiversitas teritip dewasa di Pelabuhan Tanjung Intan Cilacap juga terhitung rendah. Lingkungan pelabuhan hanya dihuni oleh 4 spesies yang juga relatif kosmopolit (Gambar 2). Tidak ada catatan adanya spesies asing di Pelabuhan Cilacap, hal ini kemungkinan karena frekwensi kapal yang datang dari zona zoogeografis yang berbeda (misalnya: daerah tropis benua Amerika) dengan kondisi lingkungan yang hampir sama, jarang terjadi. Oleh karena itu peluang terjadinya introduksi spesies asing kecil. Disamping itu kondisi lingkungan pelabuhan yang tercemar menjadi pembatas bagi spesies invasive untuk terintroduksi.
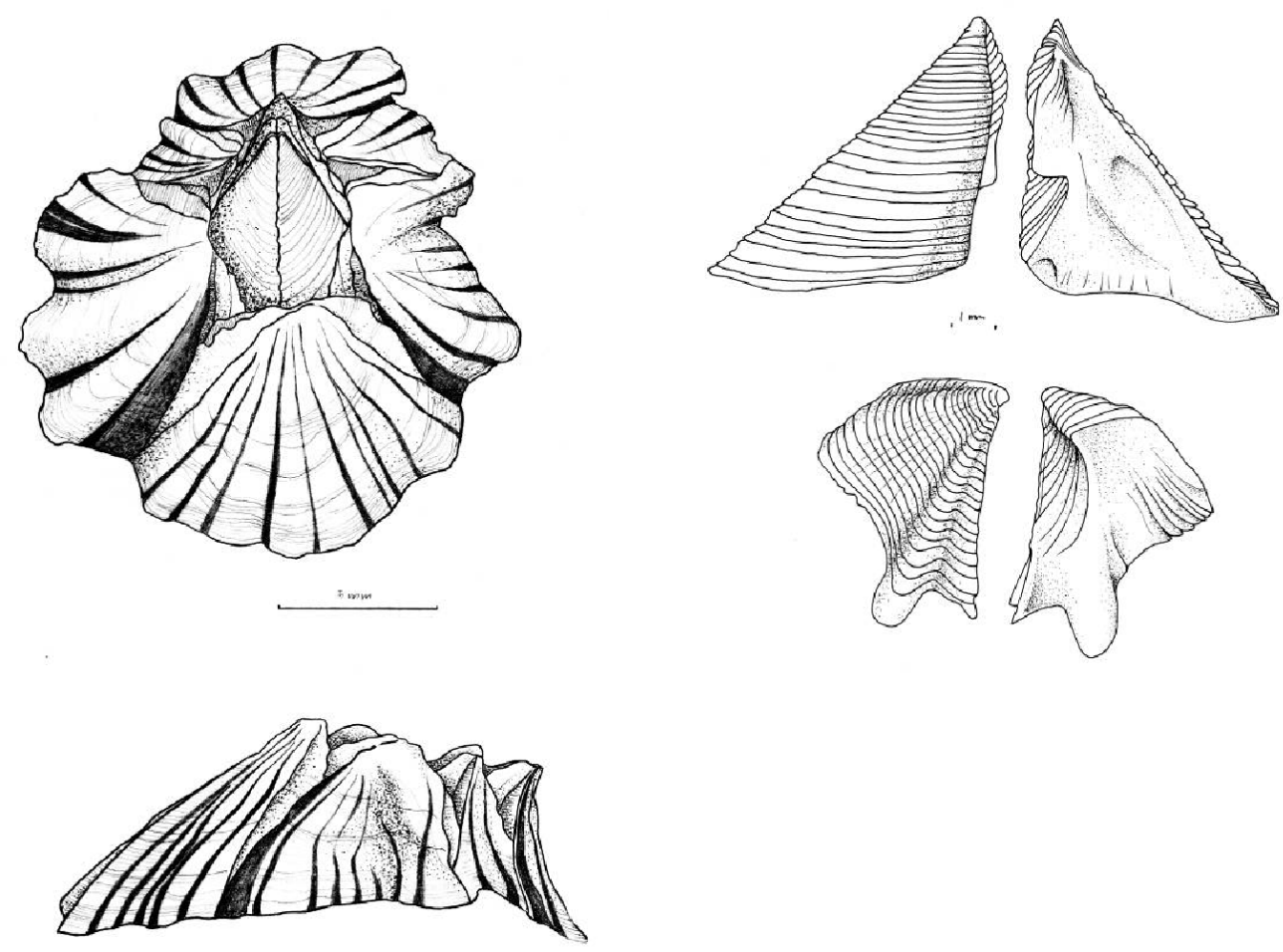

Gambar 3. Sketsa Amphibalanus amphitrite. Kiri atas = tampak apikal dan kiri bawah = tampak lateral $;$ kanan atas $=$ scutum dan kanan bawah $=$ tergum.

Figure 2. Skets of Amphibalanus Amphitrite. Upper left = apical view and lower left $=$ lateral view; upper right = scutum and lower right= tergum

Data pengambilan sampel larva teritip tidak berhasil diperoleh karena kapal sudah membuang air balas di laut lepas sebelum memasuki Pelabuhan Tanjung Intan Cilacap, atau kapal datang dengan muatan penuh sehingga kapal tidak memuat air balas dari lingkungan perairan pelabuhan asal. Pengambilan sisa air balas di dalam tangki balas kapal gagal dilakukan karena tidak mendapatkan ijin dari semua pengelola kapal dengan alasan keamanaan, meskipun tim peneliti memiliki ijin dari Administrator Pelabuhan 
Tanjung Intan Cilacap. Sehingga sulit sekali untuk melihat kemungkinan adanya spesies asing yang terbawa dalam bentuk larva.

Keempat teritip yang ditemukan di pelabuhan Tanjung Intan Cilacap, semuanya adalah bagian dari fauna teritip Indo-West Pacific yang distribusi globalnya ditunjukan dalam peta zoogeogragis pada Gambar 4. Dapat dilihat di peta bahwa teritip $A$. amphitrite adalah spesies kosmopolit, tidak hanya tersebar di Indo-West Pacific tapi juga tersebar di seluruh dunia. Spesies ini merupakan ikon dari kelompok teritip karena jenis ini adalah tipe jenis (type species) dari Balanomorpha, yang umum dikenal orang sebagai teritip.

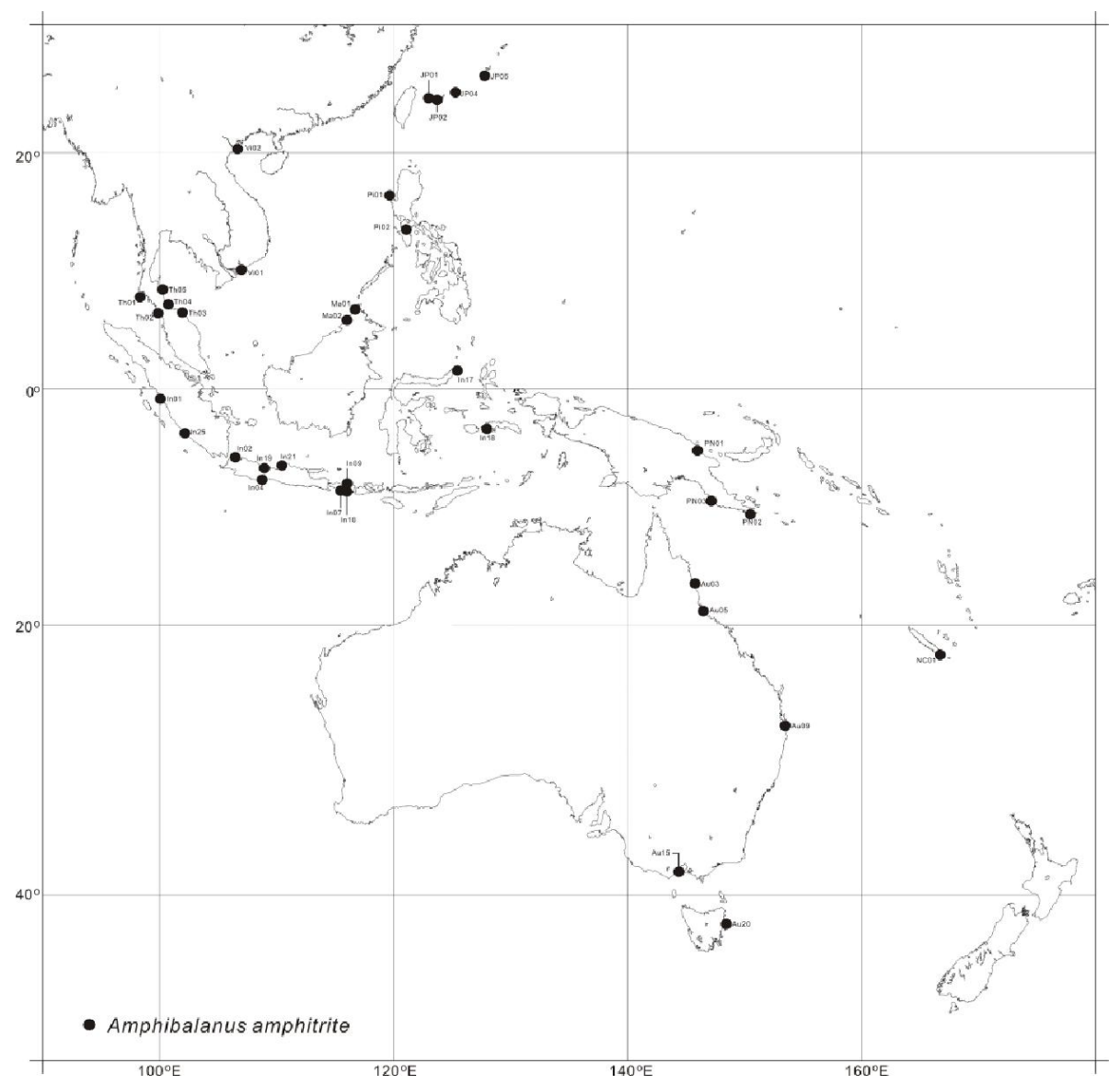

Gambar 4. Peta zoogeografis Amphibalanus amphitrite (spesies yang ditemukan di lambung kapal internasional di Tanjung Intan Cilacap) di Indo-West Pacific

Figure 4. Zoogeographic map of Amphibalanus Amphitrite (species found at ship's hull in Tanjung Intan Port Cilacap) in Indo-West Pacific

\section{Kesimpulan}


Kesimpulan yang bisa diambil dari penelitian ini adalah, diversitas teritip pada lambung kapal internasional yang singgah di Pelabuhan Tanjung Intan Cilacap sangat rendah (1 spesies; Amphibalanus amphitrite). Hal ini karena rata-rata kondisi lambung kapal masih bagus dengan cat yang relatif baru. Diversitas teritip di lingkungan pelabuhan juga relatif rendah (4 spesies; $A$. amphitrite, $A$. variegatus, $A$. reticulatus, dan Chthamalus malayensis).

\section{Daftar Pustaka}

Advisory Committee on the Marine Environment, 2001. Report of the Working Group on Introductions and Transfers of Marine Organisms (WGITMO), International Council for the Exploration of the Sea, Barcelona, Spain.

, 2004. Report of the Working Group on Introductions and Transfers of Marine Organisms (WGITMO), International Council for the Exploration of the Sea, Casenatico, Italy.

Colautti, R. I. and Maclsaac, H.J., 2004. A neutral terminology to define 'invasive' species. Diversity and Distributions, 10, 135-141.

Godwin L., 2003. Hull fouling of maritime vessels as a pathway for marine species invasions to the Hawaiian Islands. Biofouling, 5 (19), 123-131.

LeProvost, I., 2004. Best Practice for the Management of Introduced Marine Pests, The Global Invasive Species Programme, Australia.

Lewis, J. A., 2008. Personal communication, Environmental Compliance \& Biotechnology, Maritime Platforms Division, Defence Science \& Technology Organisation, Australia.

Otani, M., Oumi, T., Uwai, S., Hanyuda, T., Prabowo, R. E., Yamaguchi, T. and Kawai, H., 2007. Occurrence and diversity of barnacles on international ships visiting Osaka Bay, Japan, and the risk of their introduction'. Biofouling, 23 (4), 277-286.

Pimentel D., Lach L., Zuniga R., Morrison D., 2000. Environmental and economic costs of nonindigenous species in the United States. Bio-Science, 50, 53-65.

Prabowo, R. E., 2005. Biogeography of intertidal barnacle in Indonesian and surrounding seas. Master Thesis, Chiba Univ.

., 2008. Phylogeography study of two sister species, Balanus variegatus and Balanus kondakovi (Cirripedia: Balanomorpha: Balaninae) using mtCOI gene; with special reference on the phylogenetic and taxonomic revision of the Balanus amphitrite complex. Doctoral Dissertation, Chiba Univ.

Prabowo, R. E. and Yamaguchi, T., 2005. A new mangrove barnacle of the genus Fistulobalanus (Cirripedia: Amphibalaninae) from Sumbawa Island, Indonesia. J. Mar. Biol. Ass, 85: 929-936. 
Sastroutomo, S.S., Lum, K.Y., and Loke, W.H., 2005. Identification of capacity-building needs in ASEAN for the management of invasive alien species., in Identification of risks and management of invasive alien species using the IPPC framework, Proceedings of a workshop in Braunschweig, Germany 22-26 September 2003, FAO Corporate Document.

Southward A.J., Burton, R.S., Coles, S.L., Dando, P.R., DeFelice, R., Hoover, J., Parnell, P.E., Yamaguchi, T., and Newman, W.A., 1998. Invasion of Hawaiian shores by an Atlantic barnacle. Mar. Ecol.-Progress Ser, 165,119-126.

Stafford, H. and Willan, R.C., 2007. Is it a Pest? Introduced and naturalised marine animal species of Torres Strait Northern Australia. Queensland Department of Primary Industries and Fisheries, Cairns. pagg. 11

Wolff, W.J., 2005. Non-indigenous marine and estuarine species in the Netherlands. Zool. Med, 79 (1), 1-116. 